\title{
HERBICIDE EFFECTS ON Ganoderma boninense INFECTION IN OIL PALM SEEDLINGS
}

\author{
SITI HAZLINA HUSSIN*; IDRIS ABU SEMAN**; MOHD HEFNI RUSLI*; \\ MAIZATUL SURIZA MOHAMED** and ZAITON SAPAK*
}

\begin{abstract}
The use of herbicides for weed management is a common practice in oil palm plantation. However, previous studies have shown that herbicide can reduce plant susceptibility and could also cause physiological injury to plant parts such as roots which will ultimately provide entry points for pathogens. This study aimed to investigate the effect of commonly used herbicides in the oil palm plantation as a predisposing factor to Ganoderma disease development. In vitro study on 11 commercial herbicides with four different dosages have shown that the highest percentage inhibition of radial growth (PIRG) of Ganoderma boninense was recorded by paraquat dichloride treatment (100\%) followed by diuron (87\%) and monosodium methyl arsenate (MSMA) (79\%) at concentration of $100 \mathrm{\mu g} \mathrm{ml}^{-1}$. Based on nursery trial, oil palm seedlings inoculated with $\mathrm{G}$. boninense and treated with diuron showed the highest Ganoderma disease progression at $92.73 \%$ followed by seedlings treated with metsulfuron-methyl and glyphosate monoammonium (83.27\%) and by glyphosate glyphosate isopropylammonium with (73.81\%). These findings will help the oil palm industry in Malaysia to choose the best herbicides in order to mitigate the development of Ganoderma disease incidence.
\end{abstract}

Keywords: basal stem rot, Ganoderma boninense, herbicide, phytotoxicity.

Received: 1 November 2018; Accepted: 1 July 2020; Published online: 22 September 2020.

\section{INTRODUCTION}

The oil palm is an economically important crop and considered as one of the world's major sources of edible oil and a significant precursor of biodiesel fuel (Mohd Ali et al., 2012; Hameed et al., 2009). Unfortunately, it faces the threat of a devastating disease. Basal stem rot (BSR) disease caused by the fungus Ganoderma boninense is considered as the greatest threat to oil palm production in Southeast Asia including Malaysia (Ariffin et al., 2000;

\footnotetext{
Centre of Graduate Studies,

Faculty of Plantation and Agrotechnology,

Universiti Teknologi MARA, 40450 Shah Alam,

Selangor, Malaysia.

E-mail: zaiton3338@uitm.edu.my

** Malaysian Palm Oil Board,

6 Persiaran Institusi, Bandar Baru Bangi,

43000 Kajang, Selangor, Malaysia.
}

Assis et al., 2016). The disease incidence increases progressively, although slowly, but certainly erodes the profitability of this major industry. It has been reported that the economic loss due to this disease in our country is between RM 225 million to RM 1.5 billion (up to USD 500 million) a year (Arif et al., 2011). Several control methods have been introduced and practised to control BSR disease including cultural practices, chemical and biological controls. Cultural practices such as surgery, soil mounding, sanitation by removing and destroying infected old palm stumps, root masses and ploughing along the new planting row at the replanting area have been applied to manage BSR. Thorough studies have been conducted on managing the disease with chemical fungicides such as hexaconazole (Idris et al., 2004a) and biological control agents such as endophytic microorganisms (Sapak et al., 2008), Trichoderma (Mohd and Faridah, 2008; Nusaibah et al., 2017) and mycorrhizal fungi (Sundram et al., 2015). The research findings showed 
the potential of these approaches in delaying the disease and prolonging the economic life-span of the infected oil palms. Apart from these control approaches, herbicides commonly used to manage weeds in oil palm plantation could be explored for their effects towards $G$. boninense. The side effects of herbicides on plant pathogens and hosts either promoting or supressing the disease development have been discussed extensively by researchers (Hess, 2018; Johal and Huber, 2009; Manju et al., 2015; Sanogo et al., 2000). The interaction of herbidices with $G$. boninense and oil palm roots, however, have not yet fully investigated and tested. Therefore, this study aimed to assess the side effects of several herbicides commonly used in oil palm plantation on G. boninense development in oil palm seedlings.

\section{MATERIALS AND METHODS}

\section{Herbicides and Source of BSR Pathogen}

Eleven herbicides commonly used in oil palm plantations were selected in these experimental studies (Table 1). A pure culture of fungal pathogen G. boninense (PER 71) was obtained from the Malaysian Palm Oil Board (MPOB), Bangi, Selangor. The fungus was grown on potato dextrose agar (PDA) for eight days and incubated at room temperature $\left(28^{\circ} \mathrm{C} \pm 2^{\circ} \mathrm{C}\right)$.

TABLE 1. SELECTION OF HERBICIDES WITH DIFFERENT ACTIVE INGREDIENTS AND MODES OF ACTION

\begin{tabular}{lcc}
\hline Active ingredient of herbicides & $\begin{array}{c}\text { Mode of } \\
\text { action }\end{array}$ & $\begin{array}{c}\text { Product rate } \\
\text { (litre ha }^{-1} \text { ) }\end{array}$ \\
\hline Metsulfuron-methyl & Systemic & 17 \\
Triclopyr butoxy ethyl ester & Systemic & 33 \\
Fluroxypyr-1-methyl heptyl ester & Systemic & 22 \\
Glyphosate isopropylammonium & Systemic & 60 \\
Glyphosate monoammonium & Systemic & 34 \\
2, 4-D dimethylamine & Systemic & 49 \\
Diuron & Systemic & 45 \\
Sodium chlorate & Contact & 180 \\
Glufosinate ammonium & Contact & 330 \\
Paraquat dichloride & Contact & 235 \\
Monosodium methyl arsenate & Contact & 125 \\
\hline
\end{tabular}

\section{Direct Effect of Eleven Herbicides on G. boninense Radial Growth}

Inhibitions of radial growth of G. boninense by 11 herbicides were assessed using a poison agar technique as previously reported by Marzuki et al. (2015). A mycelial disc, $5 \mathrm{~mm}$ diameter, was obtained from the actively growing G. boninense margins and was placed on the middle of a poison agar plate $(9 \mathrm{~cm}$ in diameter). The poison agar was prepared by mixing PDA with herbicide at four different concentrations which were 1, 10, 100 and $1000 \mu \mathrm{g} \mathrm{ml}^{-1}$. For each herbicide concentration, five replicates of the plate agar were used to inoculate with the mycelial disc of the pathogen. All inoculated poison agar plates were incubated at room temperature $\left(28^{\circ} \mathrm{C} \pm 2^{\circ} \mathrm{C}\right)$ for eight days. A mycelial disc plated on PDA without any herbicides served as a control treatment. All of the treatments were distributed in a completely randomised design. After the incubation period, the radial growth of $G$. boninense on the poison agar plates was measured in percentage inhibition of radial growth (PIRG) by using Equation (1) by Skidmore and Dikson (1976).

$$
\mathrm{PIRG}=r_{1}-r_{2} / r_{1} \times 100
$$

Equation (1)

where $r_{1}$ is the radial growth of G. boninense in a control plate and $r_{2}$ is the radial growth of G. boninense in the poison agar plate.

\section{Effects of Selected Herbicides in Suppressing G. boninense on Oil Palm Seedlings}

The experiment was conducted in an open nursery area at Bandar Baru Bangi, Selangor, Malaysia. Oil palm seedlings were supplied by the Federal Land Development Authority (Felda), Malaysia. Twelve months old dura $\mathrm{x}$ pisifera crosses oil palm seedlings were grown in large polybag $(38.1 \mathrm{~cm} \times 50.8 \mathrm{~cm})$. Seven commonly used herbicides namely metsulfron-methyl, triclopyr butoxy ethyl ester, paraquat dichloride, glyphosate isopropylammonium, glyphosate monoammonium, diuron and monosodium methyl arsenate based on the results from in vitro experiment were used in this study (selected from Table 1). A stock solution of each herbicide was made based on the manufactures recommendation for field application. Ganoderma boninense rubber wood block (RWB) inoculums $(3 \mathrm{~cm} \times 3 \mathrm{~cm} \times 6 \mathrm{~cm})$ were prepared as described by Sapak et al. (2008). The seedlings were artificially inoculated with $G$. boninense RWB via root inoculation technique (Idris et al., 2004b). The seedlings were treated with selected herbicides that previously prepared before inoculation with the pathogen. Each herbicide was drenched carefully around the oil palm seedling collar without contact with the stem, fronds and stalk as suggested by Tan and Chan (1994). The experiment was laid down in a completely randomised design. Each herbicide treatment was replicated three times consisted of 10 seedlings per treatment. The seedlings without pathogen treated with herbicides were used as a 
negative control and the seedlings with pathogen but without herbicide served as a positive control. The effects of herbicides on BSR disease development were assessed monthly based on disease incidence (DI) and disease severity (DS). The experiment was conducted for 15 months.

The assessment of DI was performed according to the method proposed by Sapak et al. (2008). In this method, oil palm seedlings were visually assessed as infected seedlings once the seedlings displayed disease symptoms of chlorosis and necrosis of leaves, with or without production of white mycelium or fruiting bodies of G. boninense. Percentage of DI was then calculated based on Equation (2) by Campbell and Maiden (1990).

$$
\text { DI }(\%)=\frac{\begin{array}{c}
\text { Total number of } \\
\text { seedlings } \\
\text { infected by BSR }
\end{array}}{\begin{array}{c}
\text { Total number of } \\
\text { seedlings assessed }
\end{array}} \times 100 \quad \text { Equation (2) }
$$

A reduction of disease incidence due to herbicide effects was then measured as the area under the disease progress curve (AUDPC) and disease reduction (DR). The value of AUDPC was calculated based on an Equation (3) by Campbell and Madden (1990).

$$
\text { AUDPC }\left(\text { Unit }^{2}\right)=\sum_{i-1}^{n-1}\left[\frac{y_{i+} y_{i+1}}{2}\right] \times\left(t_{i+1}-t_{1}\right) \quad \text { Equation (3) }
$$

where $y_{i}$ is an assessment of a DI at the $i$ th observation, $t_{i}$ is time at the $i$ th observation, and $n$ is the total number of observations. Meanwhile, $D R$ value was calculated based on an Equation (4) of Sivan and Chet (1986).

$$
D R=(1-D T \mid D C) \times 100
$$

Equation (4)

where $D C$ is a percentage of DI in the positive control treatment and DT is an AUDPC of the herbicide treatment.

\section{DS}

DS was measured based on disease severity foliar index (DSFI) and disease severity internal symptoms (DSIS) of the infected tissues. Development of external foliar symptoms on oil palm seedlings was recorded at a sequence of 1 , $3,6,9,12$ and 15 months after treatment. The oil palm seedlings with BSR disease foliar symptoms were scored based on five class indexes which are $0=$ asymptomatic seedling without appearance of white fungal mass (mycelium) fruiting body and without any foliar symptoms such as chlorosis and necrotic of leaves, 1 = appearance of white fungal mass and/or fruiting body but without any foliar symptoms, 2 = appearance of white fungal mass and/or fruiting body with evidence of less than $25 \%$ of leaf areas showing foliar symptoms, $3=$ appearance of white fungal mass and/or fruiting body with evidence of more than $26 \%$ of leaves with foliar symptoms, and $4=$ appearance of white fungal mass and / or fruiting body with evidence of more than $75 \%$ of leaves with foliar symptoms. The DSFI was then calculated based on an Equation (5) as proposed by Mohd and Faridah (2008).

$$
\text { DSFI }=\frac{\left.\sum(\mathrm{A} \times \mathrm{B}) \times 100\right)}{\sum \mathrm{n} \times 4}
$$

Equation (5)

where $A$ is the disease scale ranged from 0 to $4, B$ is a total number of plants showing that disease class per treatment, $n$ is the total number of replicate with 4 indicating the highest level of disease index assessment. Meanwhile, the DSIS was assessed based on internal symptoms of BSR disease severity index on root (DSIR) and disease severity index on bole (DSIB) tissues of oil palm seedlings. This assessment was conducted during the final stage of experiment by using a destructive sampling method. Prior to the DSIS assessment, Ganoderma selective media were used to confirm the presence of $G$. boninense as the infected root and bole tissues would produce a halo zone on the media (Ariffin and Idris, 1991). The infected seedlings were then split longitudinally at the inoculated root point to examine the extension of disease symptoms to the bole tissue by using a grid method with size of $1 \mathrm{~cm}^{2}$ per grid (Sapak et al., 2008). The disease symptom of rotten tissues caused by G. boninense was rated based on a disease scale as suggested by Nur Sabrina et al. (2012) as $0=$ asymptomatic root and bole tissues without any internal symptom of rot, $1=$ root and bole tissues displaying $<20 \%$ symptom of rot, 2 root and bole tissues displaying 20\%-50\% symptom of rot, 3 = root and bole tissues displaying $>50 \%-80 \%$ symptom of rot and $4=$ root and bole tissues displaying $>80 \%$ symptom of rot. Equation (6) was applied to calculate the internal severity of the infected seedlings (Liu et al., 1995).

$$
\text { DSIS }(\%)=\frac{\begin{array}{c}
\text { Number of } \\
\text { seedlings in the } \\
\text { scoring } \\
\times \text { scoring scale }
\end{array}}{\begin{array}{c}
\text { Total number of } \\
\text { seedlings assessed } \\
\times \text { the score }
\end{array}} \times 100 \quad \text { Equation (6) }
$$

\section{Data Analysis}

All collected data were subjected to the analysis of variance (ANOVA) and Turkey's Test $(\mathrm{P} \leq 0.05)$ 
by using $S A S^{\circledR}$ statistical packages version 9.0 (SAS Institute Carey, North Carolina, USA).

\section{RESULTS AND DISCUSSION}

Effects of Herbicides on Radial Growth of $G$. boninense in vitro

Results of in vitro study revealed that PIRG of G. boninense upon direct exposure to 11 herbicides at different concentrations are varied as presented in Table 2. The highest PIRG of G. boninense was recorded in the paraquat dichloride treatment at both concentrations of 100 and $1000 \mu \mathrm{g} \mathrm{ml} \mathrm{m}^{-1}$ which gave $100.0 \%$ of PIRG or zero growth of G. boninense. This result indicated that paraquat at $100 \mu \mathrm{g} \mathrm{ml}^{-1}$ would be an adequate concentration to totally inhibit the growth of $G$. boninense. The ability of paraquat to inhibit plant pathogen has been discussed by Toubia-Rhame et al. (1995) and Duke et al. (2007a) where both studies have reported that paraquat was able to suppress the growth of Dreschlera teres in barley via direct toxic to the pathogen. Previous study by Smith and Lyon (2006) also showed that paraquat could inhibit other fungal species such as Mucor sp., Penicillium sp. and Aspergillus sp. up to $70.0 \%$ of PIRG. Nevertheless, low concentrations of paraquat dichloride at $1 \mu \mathrm{g} \mathrm{ml}^{-1}$ and $10 \mu \mathrm{g} \mathrm{ml} \mathrm{m}^{-1} \mathrm{did}$ not inhibit the growth of $G$. boninense as evidenced by the pathogen growing on the poison agar plates. The second highest PIRG value at the concentration of $100 \mu \mathrm{g} \mathrm{ml} \mathrm{m}^{-1}$ was recorded by diuron at $87.2 \%$. Monosodium methyl arsenate and glufosinate ammonium recorded PIRG values of $79.5 \%$ and
$72.2 \%$, respectively. Furthermore, at the highest concentration of $1000 \mu \mathrm{g} \mathrm{ml}^{-1}$, herbicides of diuron, glufosinate ammonium and monosodium methyl arsenate gave similar effect on the pathogen growth with PIRG values between 93.0\%-94.0\%. In contrast, the less effective herbicides on suppression of radial growth of pathogen at the highest concentration $\left(1000 \mu \mathrm{g} \mathrm{ml} \mathrm{m}^{-1}\right)$ were observed in the treatment of sodium chlorate with only $35.5 \%$, followed by $2-4-$ D dimethylamine, glyphosate isopropylammonium and metsulfuron-methyl with PIRG values of $62.2 \%$, $63.3 \%$ and $65 \%$, respectively.

\section{Phytotoxicity Effect of Herbicides on Ganoderma Disease Incidence}

Disease progression. The external symptoms of Ganoderma infection were observed during the course of the experiments. These symptoms included the progressive yellowing of lower leaves, the subsequent desiccation from the oldest to the younger leaves, and the rapid development of sphorophore, like small white button and fruiting bodies. Assessment of the exposure data presented here indicated that the above-mentioned herbicides used in oil palm plantation would have the potential to inhibit and encourage the aggressiveness of fungal G. boninense populations upon direct exposure in vitro. However, due to natural processes in the field, the inhibitory effect on the growth of G. boninense was different depending on the mode of actions and active ingredient of the herbicides. Herbicides treated in in vitro studies caused significant reduction to growth and development of $G$. boninense. Johnston et al. (1980) reported that fungal pathogens

TABLE 2. EFFECT OF DIFFERENT HERBICIDES AT DIFFERENT CONCENTRATIONS ON RADIAL GROWTH OF G. boninense ON POISON AGAR (cm)

\begin{tabular}{|c|c|c|c|c|}
\hline \multirow{2}{*}{ Active ingredient } & \multicolumn{4}{|c|}{ Concentration $\left(\mu \mathrm{g} \mathrm{ml}^{-1}\right)$} \\
\hline & 1 & 10 & 100 & 1000 \\
\hline Diuron & $6.68 \pm 1.52^{c}$ & $8.88 \pm 2.32^{c}$ & $87.22 \pm 1.52^{\mathrm{b}}$ & $93.86 \pm 1.24^{\mathrm{a}}$ \\
\hline Glyphosate monoammonium & $4.48 \pm 1.52^{\mathrm{d}}$ & $8.88 \pm 2.32^{c}$ & $31.68 \pm 1.52^{\mathrm{b}}$ & $74.44 \pm 2.32^{\mathrm{a}}$ \\
\hline Fluroxypyr-1-methyl heptyl ester & $3.36 \pm 1.24^{c}$ & $34.42 \pm 1.52^{\mathrm{b}}$ & $35.54 \pm 2.32^{\mathrm{b}}$ & $71.10 \pm 2.48^{\mathrm{a}}$ \\
\hline Triclopyr butoxy ethyl ester & $3.36 \pm 1.24^{c}$ & $33.88 \pm 2.32^{b}$ & $35.54 \pm 2.32^{\mathrm{b}}$ & $71.10 \pm 2.48^{\mathrm{a}}$ \\
\hline 2,4-D dimethylamine & $10.00 \pm 3.17^{\mathrm{d}}$ & $23.88 \pm 4.21^{c}$ & $35.54 \pm 2.32^{\mathrm{b}}$ & $62.22 \pm 3.17^{\mathrm{a}}$ \\
\hline Sodium chlorate & $5.58 \pm 3.40^{\mathrm{b}}$ & $11.68 \pm 4.97^{\mathrm{b}}$ & $12.20 \pm 5.41^{\mathrm{b}}$ & $35.54 \pm 1.81^{\mathrm{a}}$ \\
\hline
\end{tabular}

Note: Means \pm standard error. Values sharing same letters between columns differ non-significantly $(\mathrm{P} \leq 0.05)$. 
may also differ in their response to the herbicides in field conditions. Anderson and Kolmer (2005) also reported that the results from greenhouse and field study confirmed that application of glyphosate can reduce or eliminate plant diseases caused by Puccinia triticina and also Puccinia graminis.

Oil palm seedlings treated with herbicides and inoculated with G. boninense showed zero incidences in all treatments for the first two months of observation. Formation of sporophore or small white button of G. boninense was then observed in all treatments except for triclopyr butoxy ethyl ester at three months after treatment (Table 3). Based on the assessment after 15 months, seedlings treated with diuron showed the highest DI value at $92.73 \%$. Recent study by Adejoro et al. (2019) recorded that Corchorus olitorius plants were treated with diuron displayed the disease symptoms of dieback and stunted growth. Their study also recorded a reduction in soil microbial population due to diuron application. Furthermore, Lima et al. (2017) also reported that the application of diuron could cause anatomical and physiological injuries to Bauhina variegate. Based on these studies, it is higly possible that the application of diuron directly (into the polybag) could cause injury to the root system thus provided an opening for the pathogen to infect the plant. The second highest value of DI was recorded in the treatments of metsulfuronmethyl and glyphosate monoammonium with the same value at $83.27 \%$ followed by glyphosate isopropyl ammonium at $73.81 \%$. On the other hand, the seedlings treated with triclopyr butoxy ethyl ester recorded the lowest DI value of $56.62 \%$. In the case of auxin like herbicide such as triclopyr butoxy ethyl ester, volatility and drift could cause injury to non-target plant (Sciumbato et al., 2004), thus it is consistent with the results obtained that even though triclopyr butoxy ethyl ester showed the lowest DI value, the DI was still significantly high.

The disease development was also evaluated using the AUDPC. The AUDPC is a quantitative summary of the disease intensity over time and can be used for best management strategies. The percentage of DR and AUDPC are shown in Table 4. AUDPC was calculated based on the DI. In this study, treatment with the lowest AUDPC values indicated low severity of disease in the treated seedlings by the selected herbicides. The seedlings treated with triclopyr butoxy ethyl ester showed

TABLE 3. DISEASE INCIDENCE (\%) OBSERVED ON OIL PALM SEEDLINGS 1 TO 15 MONTHS AFTER TREATMENT WITH HERBICIDES AND INOCULATION WITH G. boninense

\begin{tabular}{lcccccc}
\hline \multirow{2}{*}{ Active ingredient } & \multicolumn{5}{c}{ Month after treatment } \\
\cline { 2 - 7 } & $\mathbf{1}$ & $\mathbf{3}$ & $\mathbf{6}$ & $\mathbf{9}$ & $\mathbf{1 2}$ & $\mathbf{1 5}$ \\
\hline Metsulfuron-methyl & 0 & $34.15^{\mathrm{c}}$ & $56.07^{\mathrm{a}}$ & $75.54^{\mathrm{b}}$ & $83.27^{\mathrm{a}}$ & $83.27^{\mathrm{b}}$ \\
Triclopyr butoxy ethyl ester & 0 & $0.00 \mathrm{e}$ & $34.15^{\mathrm{c}}$ & $41.88^{\mathrm{e}}$ & $48.88^{\mathrm{d}}$ & $56.62^{\mathrm{e}}$ \\
Paraquat dichloride & 0 & $27.14^{\mathrm{d}}$ & $48.88^{\mathrm{b}}$ & $56.62^{\mathrm{d}}$ & $64.35^{\mathrm{c}}$ & $64.35^{\mathrm{d}}$ \\
Glyphosate isopropylammonium & 0 & $27.14^{\mathrm{d}}$ & $48.88^{\mathrm{b}}$ & $56.62^{\mathrm{d}}$ & $73.81^{\mathrm{b}}$ & $73.81^{\mathrm{c}}$ \\
Glyphosate monoammonium & 0 & $27.14^{\mathrm{d}}$ & $41.15^{\mathrm{bc}}$ & $83.27^{\mathrm{a}}$ & $83.27^{\mathrm{a}}$ & $83.27^{\mathrm{b}}$ \\
Diuron & 0 & $56.62^{\mathrm{a}}$ & $56.62^{\mathrm{a}}$ & $73.81^{\mathrm{b}}$ & $73.81^{\mathrm{b}}$ & $92.73^{\mathrm{a}}$ \\
Monosodium methyl arsenate & 0 & $49.61^{\mathrm{b}}$ & $49.61^{\mathrm{b}}$ & $64.35^{\mathrm{c}}$ & $64.35^{\mathrm{c}}$ & $83.27^{\mathrm{b}}$ \\
Control & 0 & $56.62^{\mathrm{a}}$ & $56.62^{\mathrm{a}}$ & $73.81^{\mathrm{b}}$ & $73.81^{\mathrm{b}}$ & $92.73^{\mathrm{a}}$ \\
\hline
\end{tabular}

Note: Means \pm standard error. Values sharing same letters between columns differ non-significantly $(\mathrm{P} \leq 0.05)$.

TABLE 4. EFFECTIVENESS OF DIFFERENT HERBICIDES IN CONTROLLING BASAL STEM ROT DISEASE CAUSED BY G. boninense ON OIL PALM SEEDLINGS MEASURED AS DISEASE INCIDENCE BASED ON AREA UNDER DISEASE PROGRESS CURVE (AUDPC) AND DISEASE REDUCTION (DR)

\begin{tabular}{lcc}
\hline Treatment & AUDPC $\left(\mathbf{u n i t}^{2}\right)$ & DR (\%) \\
\hline Metsulfuron-methyl & 854.92 & 4.30 \\
Triclopyr butoxy ethyl ester & 459.66 & 48.55 \\
Paraquat dichloride & 673.93 & 24.56 \\
Glyphosate isopropylammonium & 716.50 & 19.80 \\
Glyphosate monoammonium & 815.83 & 8.68 \\
Diuron & 893.37 & 0.00 \\
Monosodium methyl arsenate & 783.86 & 12.34 \\
\hline
\end{tabular}


the lowest AUDPC of 459.66 unit $^{2}$, followed by the paraquat dichloride $\left(673.93\right.$ unit $\left.^{2}\right)$ and glyphosate isopropylammonium (716.50 unit $\left.^{2}\right)$. Thus, triclopyr butoxy ethyl ester had the most effect on Ganoderma disease development with DR at $48.55 \%$ followed by paraquat dichloride $(24.56 \%)$ and glyphosate isopropylammonium (19.80\%). The lowest DR was recorded by diuron at $0 \%$ unit indicating no reduction in suppression the BSR and followed by metsulfuron-methyl $4.30 \%$, glyphosate monoammonium $8.68 \%$ and monosodium methyl arsenate $12.34 \%$.

The lower percentage of DI, AUDPC and higher value of DR in the seedlings treated with the selected herbicides suggested that the herbicides have a potential to inhibit the growth of G. boninense.

The external symptoms of DSFI at 15 months also showed that seedlings treated with diuron recorded the highest DSFI value at $85 \%$ whilst the metsulfron-methyl shown the lowest DSFI at $28.33 \%$. The second lowest were recorded by paraquat dichloride and monosodium methyl arsenate with DSFI value of $56.67 \%$, followed by the glyphosate monoammonium at 50\% (Table 5).

At the end of the experiment, the destructive sampling was carried out at 15 months to assess the extent of root rot and bole decay. The seedlings were sampled and their roots washed under running water to assess the extent of the root rot. The bole was cut longitudinally for assessment of percentage infection of bole tissues and roots. Severe root rot was seen in seedlings under positive control treatment which suffered foliar desiccation. The highest level of root rot decay on DSIR, with extensive colonisation of fungal masses on the root surface, was observed in seedlings treated by diuron in which $41.11 \%$ of root showed brown discolouration whilst the lowest DSIR value was shown by seedlings treated with metsulfuron-methyl at $21.67 \%$ (Table 6). In relation to DSIR, seedlings treated by diuron also showed the highest DSIB at at $40.00 \%$ whereas the lowest DSIB was recorded by seedlings treated by metsulfuron-methyl and paraquat dichloride with the same value at $21.67 \%$.

TABLE 5. EFFECTIVENESS OF DIFFERENT HERBICIDES ON CONTROLLING BASAL STEM ROT DISEASE CAUSED BY G. boninense ON OIL PALM SEEDLINGS BASED ON DISEASE SEVERITY FOLIAR INDEX (\%)

\begin{tabular}{|c|c|c|c|c|c|c|}
\hline \multirow{2}{*}{ Herbicide (active ingredient) } & \multicolumn{6}{|c|}{ Observation month } \\
\hline & 1 & 3 & 6 & 9 & 12 & 15 \\
\hline Metsulfuron-methyl & $0.00^{\mathrm{a}} \pm 0.00$ & $6.67^{\mathrm{abc}} \pm 0.48$ & $15.00^{\mathrm{ab}} \pm 0.55$ & $16.67^{\mathrm{cd}} \pm 0.33$ & $30.00^{c} \pm 0.59$ & $28.33^{\mathrm{d}} \pm 1.28$ \\
\hline Triclopyr butoxy ethyl ester & $5.00^{\mathrm{a}} \pm 0.33$ & $11.67^{\mathrm{abc}} \pm 0.51$ & $11.67^{\mathrm{ab}} \pm 0.33$ & $26.67^{\mathrm{bcd}} \pm 0.48$ & $31.67^{\complement} \pm 0.94$ & $63.00^{\mathrm{bc}} \pm 1.69$ \\
\hline Paraquat dichloride & $3.33^{\mathrm{a}} \pm 0.18$ & $8.33^{\mathrm{abc}} \pm 0.51$ & $13.33^{\mathrm{ab}} \pm 0.30$ & $18.33^{\mathrm{cd}} \pm 0.95$ & $45.00^{\mathrm{abc}} \pm 1.13$ & $56.67^{\mathrm{bc}} \pm 0.73$ \\
\hline Glyphosate isopropylammonium & $3.33^{\mathrm{a}} \pm 0.18$ & $21.67^{\mathrm{ab}} \pm 0.74$ & $23.33^{\mathrm{ab}} \pm 0.55$ & $38.33^{\mathrm{b}} \pm 0.96$ & $41.67^{\mathrm{bc}} \pm 1.34$ & $70.0^{\mathrm{ab}} \pm 1.03$ \\
\hline Glyphosate monoammonium & $0.00^{\mathrm{a}} \pm 0.00$ & $3.33^{\mathrm{bc}} \pm 0.33$ & $5.00^{\mathrm{b}} \pm 0.45$ & $13.33^{\mathrm{d}} \pm 0.33$ & $30.00^{c} \pm 0.45$ & $50.00^{\mathrm{d}} \pm 1.02$ \\
\hline Diuron & $6.67^{\mathrm{a}} \pm 0.45$ & $23.33^{\mathrm{a}} \pm 0.66$ & $28.33^{\mathrm{a}} \pm 0.15$ & $60.00^{\mathrm{a}} \pm 1.39$ & $60.0^{\mathrm{a}} \pm 0.89$ & $85.00^{\mathrm{a}} \pm 1.05$ \\
\hline Monosodium methyl arsenate & $11.67^{\mathrm{a}} \pm 0.63$ & $21.67^{\mathrm{ab}} \pm 0.66$ & $21.67^{\mathrm{ab}} \pm 0.70$ & $30.00^{\mathrm{bc}} \pm 0.89$ & $45.00^{\mathrm{abc}} \pm 0.96$ & $56.67^{\mathrm{bc}} \pm 1.10$ \\
\hline Control & $0.00^{\mathrm{a}} \pm 0.00$ & $1.67^{c} \pm 0.51$ & $5.00^{\mathrm{b}} \pm 0.51$ & $16.70^{\mathrm{cd}} \pm 0.64$ & $38.33^{c} \pm 1.20$ & $63.0^{\mathrm{bc}} \pm 1.10$ \\
\hline
\end{tabular}

Note: Mean \pm standard deviation. Values sharing same letters between columns differ non-significantly $(\mathrm{P} \leq 0.05)$.

TABLE 6. DISEASE SEVERITY OBSERVED IN ROOT (DSIR) AND DISEASE SEVERITY IN BOLE (DSIB) TISSUES OF OIL PALM SEEDLINGS AT 15 MONTHS AFTER TREATED WITH HERBICIDES AND G. boninense INOCULATION

\begin{tabular}{lcc}
\hline Treatment & DSIR \pm SD & DSIB \pm SD \\
\hline Metsulfuron-methyl & $21.67 \pm 1.26^{\mathrm{a}}$ & $21.67 \pm 1.32^{\mathrm{a}}$ \\
Triclopyr butoxy ethyl ester & $31.67 \pm 1.28^{\mathrm{a}}$ & $25.00 \pm 1.21^{\mathrm{a}}$ \\
Paraquat dichloride & $28.89 \pm 1.47^{\mathrm{a}}$ & $21.70 \pm 1.37^{\mathrm{a}}$ \\
Glyphosate isopropylammonium & $30.00 \pm 1.31^{\mathrm{a}}$ & $25.00 \pm 1.34^{\mathrm{a}}$ \\
Glyphosate monoammonium & $40.00 \pm 1.46^{\mathrm{a}}$ & $28.33 \pm 1.34^{\mathrm{a}}$ \\
Diuron & $41.11 \pm 1.61^{\mathrm{a}}$ & $40.00 \pm 1.33^{\mathrm{a}}$ \\
Monosodium methyl arsenate & $33.33 \pm 1.63^{\mathrm{a}}$ & $28.33 \pm 1.19^{\mathrm{a}}$ \\
Control & $55.00 \pm 1.28^{\mathrm{a}}$ & $46.70 \pm 1.51^{\mathrm{a}}$
\end{tabular}

Note: Mean \pm standard deviation (SD). Values sharing same letters differ non-significantly ( $\mathrm{P} \leq 0.05)$. 


\section{CONCLUSION}

The in vitro study has shown that certain concentration of herbicides could inhibit G. boninense. The effect of herbicides on plant pathogen have been reported by many previous studies (Duke et al., 2007b). Nevertheless, most studies found that herbicides generally do not tend to move in significant quantities below the top $15 \mathrm{~cm}$ of soil. Recent findings found that $G$. boninense in oil palm roots and trunk were more persistence at $60 \mathrm{~cm}$ below soil (Sundram, 2019). Thus, although certain herbicides are toxic to $G$. boninense but due to the movement and distribution of the herbicide in the field, the herbicide will have little effect on G. boninense. Nevertheless, it is worth to note that herbicides with different mechanisms of action can also stimulate antimicrobial compound such as phytoalexins and therefore can have an effect on plant disease resistance. Nevertheless, there are limited studies on the effect of tested herbicides on plant disease resistance.

Based on the nursery study, it was evident that direct application of herbicides into root will have an adverse affect to the oil palm seedlings. Herbicides such as diuron, metsulfuron-methyl and glyphosate monoammonium that have been previously reported to cause injury to plant roots had the highest DI compared to other herbicide treatments. This information is important especially in the context of suitable application of these herbicides in the field. It is recommend that no application of herbicides should be made directly to the root or bold of oil palm seedlings.

In conclusion, this study suggests that herbicides which potentially can cause injury to oil palm seedlings should be reassessed for their application in oil palm nursery to avoid damage to oil palm which would provide entry routes for the pathogen. Neverthless, the findings in this study only provide a basic understanding on the effect of herbicides that are commonly used to control weeds to young oil palm and G. boninense based on observable symptoms. Therefore, further intensive study at cellular and molecular levels to get better understanding on the interaction between herbicides, oil palm and pathogen need to be carried out in the future.

\section{ACKNOWLEDGEMENT}

The first author gratefully acknowledges a scholarship under the Graduate Student Assistantship Scheme (GSAS) from MPOB and the Faculty of Plantation and Agrotechnology staff, Universiti Teknologi MARA for technical help and support.

\section{REFERENCES}

Adejoro, S A; Ajoke, C A and Rex, D A (2019). Effects of diuron residues on the growth performance of jute (Corchorus olitorius) plant and its rhizosphere soil microbial population. J. Biology and Life Science, 10: 35-45.

Anderson, J A and Kolmer, J A (2005). Rust control in glyphosate tolerant wheat following application of the herbicide glyphosate. Plant Disease, 89: 11361142.

Arif, M S; Roslan, A; Idris, A S and Ramle, M (2011). Economics of oil palm pests and Ganoderma disease and yield losses. Proc. of the Third MPOB-IOPRI International Seminar: Integrated Oil Palm Pests and Diseases Management. Kuala Lumpur Convention Centre, Kuala Lumpur.

Ariffin, D and Idris, A S (1991). A selective medium for the isolation of Ganoderma from diseased tissues. Proc. of the International Palm Oil Conference, Progress, Prospect and Challenges toward the $21^{\text {st }}$ Century (Modul 1, Agriculture) (Yusuf et al. eds.). PORIM, Bangi. p. 517-519.

Ariffin, D; Idris, A S and Singh, G (2000). Status of Ganoderma in oil palm. Ganoderma Diseases of Perennial Crops (Flood, J; Bridge, P and Holderness, $M$ eds.). Wallingford, United Kingdom. CABI Publishing. p. 49-68.

Assis, K; Chong, K P; Idris, A S and Ho, C M (2016). Economic loss due to Ganoderma disease in oil palm. World Academy of Science, Engineering and Technology, International Journal of Social, Behavioral, Educational, Economic, Business and Industrial Engineering, 10(2): 631-635.

Campbell, C L and Madden, L V (1990). Introduction to Plant Disease Epidemiology. New York, USA: Wiley. $532 \mathrm{pp}$.

Duke, S; Wedge, D E; Cerdeira, A L and Matallo, M B (2007a). Herbicide effects on plant disease. Outlooks on Pest Management, 8: 36-40.

Duke, S O; Wedge, D E; Cerdeira, A L and Matallo, M B (2007b). Interactions of synthetic herbicides with plant disease and microbial herbicides. Novel Biotechnologies for Biocontrol Agent Enhancement and Management (Maurizio Vurro and Jonathan Gressel eds.). Dordrecht: Springer. p. 277-296.

Hameed, BH;Lai, LF and Chin, LH(2009). Production of biodiesel from palm oil (Elaeis guineensis) using heterogeneous catalyst: An optimized process. Fuel Processing Technology, 90: 606-610. 
Hess, F D (2018). Herbicide effects on plant structure, physiology, and biochemistry. Pesticide Interactions in Crop Production (Altman, J ed.). New York: CRC Press. p. 13-34.

Idris; A S; Ismail, S and Ariffin, D (2004a). Prolonging the productive life of Ganoderma-infected palms with hexaconazole. MPOB Information Series No. 214: 4 pp.

Idris, A S; Kushairi, A; Ismail, S and Ariffin, D (2004b). Selection for partial resistance in oil palm progenies to Ganoderma basal stem rot. J. Oil Palm Res. Vol. 16: 12-18.

Johal, G S and Huber, D M (2009). Glyphosate effects on diseases of plants. European J. Agronomy, 31: 144152.

Johnston, H W; Ivany, J A and Cutcliffe, J A (1980). Effect of herbicides applied to soil on Fusarium root rot of processing peas. Plant Disease, 64: 942-943.

Lima, D A; Muller, C; Costa, A C; Batista, P F; Dalvi, V C and Domingos, M (2017). Morphoanatomical and physiological changes in Bauhinia variegate as indicators of herbicide diuron reaction. J. Ecotoxicology and Environmental Safety, 141:242-250.

Liu, L; Kloepper, J W and Tuzun, S (1995). Induction of systemic resistance in cucumber against bacterial angular leaf spot by plant growth-promoting rhizobacteria. Phytopathology, 85: 843-847.

Manju, M J; Sabu, P I; Shankarappa, T H; Jacob, C K; Prem, E and Jacob, M (2015). Effect of herbicide and fungicide application to curb Corynespora cassiicola inoculum in rubber plantation. Environment and Ecology, 33: 1293-1298.

Marzuki, N F; Goh, Y K; Tung, H J; Goh, Y K and Goh, K J (2015). Evaluation of the cultural characteristics and antagonistic activities of Cladobotryum semicirculare against Ganoderma boninense in vitro. J. Oil Palm Res. Vol. 27: 326-338.

Mohd Ali, A A; Mohd Zainudin, M H; Idris, A; Baharuddin, A S; Sulaiman, A; Matsui, T; Osaka, N; Oshibe, H; Hassan, M A and Shirai, Y (2012). Enhanced biogas production from palm oil mill effluent supplemented with untreated oil palm empty fruit bunch biomass with a change in the microbial community. Japan J. Food Engineering, 13(3): 37-41.

Mohd, Z and Faridah, A (2008). Disease suppression in Ganoderma-infected oil palm seedlings treated with Trichoderma harzianum. Plant Protection Science, 44: 101-107.
Nur Sabrina, A A; Sariah, M and Zaharah, A R (2012). Suppression of basal stem rot disease progress in oil palm (Elaeis guineensis) after copper and calcium supplementation. Pertanika J. Tropical Agricultural Science, 35: 13-24.

Nusaibah, S A; Saad, G and Hun, T G (2017). Antagonistic efficacy of Trichoderma harzianum and Bacillus cereus against Ganoderma disease of oil palm via dip, place and drench (DPD) artificial inoculation technique. Int. J. Agriculture and Biology, 19: 299-306.

Sanogo, S; Yang, X B and Scherm, H (2000). Effects of herbicides on Fusarium solani f. sp. glycines and development of sudden death syndrome in glyphosate-tolerant soybean. Phytopathology, 90: 57-66.

Sapak, Z; Meon, S and Ahmad, Z A M (2008). Effect of endophytic bacteria on growth and suppression of Ganoderma infection in oil palm. Int. J. Agriculture and Biology, 10: 127-132.

Sciumbato, A S; Chandler, J M; Senseman, S A; Bovey, R W and Smith, K L (2004). Determining exposure to auxin-like herbicides. I. Quantifying injury to cotton and soybean. Weed Technology, 18: 1125-1134.

Sivan, A and Chet, I (1986). Biological control of Fusarium spp. in cotton, wheat and muskmelon by Trichoderma harzianum. J. Phytopathology, 116: 39-47.

Skidmore, A M and Dickinson, C H (1976). Colony interactions and hyphal interference between Septoria nodorum and phylloplane fungi. Transactions of the British Mycological Society, 66: 57-64.

Smith, S and Lyon, A (2006). The uptake of paraquat by soil fungi. New Phytologist, (76): 479-484.

Sundram, S; Meon, S; Seman, I A and Othman, R (2015). Application of arbuscular mycorrhizal fungi with Pseudomonas aeruginosa UPMP3 reduces the development of Ganoderma basal stem rot disease in oil palm seedlings. Mycorrhiza, 25: 387-397.

Sundram, S (2019). Ganoderma biology, etiology and epidemiology. Proc. of International Seminar on Breeeding for Ganoderma Tolerance in Oil Palm. Kuala Lumpur Convention Centre Kuala Lumpur.

Tan, C H and Chan, C L (1994). Injury symptoms on young oil palms induced by topical and basal herbicides. The Planter, 70: 341-358.

Toubia-Rahme, H; Ali-Haimoud, D E; Barrault, G and Albertini, L (1995). Inhibition of Drechslera teres sclerotioid formation in barley straw by application of glyphosate or paraquat. Plant Disease, 79: 595-598. 